Article

\title{
A Response Surface Methodology (RSM) Approach for Optimizing the Attenuation of Human IgE-Reactivity to $\beta$-Lactoglobulin $(\beta$-Lg) by Hydrostatic High Pressure Processing
}

\author{
Xin Sun ${ }^{1}$, Jialing Vivien Chua ${ }^{1}$, Quynh Anh Le ${ }^{1}$, Francisco J. Trujillo ${ }^{1}$, Mi-Hwa Oh ${ }^{2}$, Dianne E. Campbell ${ }^{3}$, \\ Sam Mehr ${ }^{3}$ and Nanju Alice Lee ${ }^{1, *(D)}$ \\ 1 School of Chemical Engineering, University of New South Wales, Syndey, NSW 2052, Australia; \\ xinsun85@gmail.com (X.S.); vivien.j.chua@gmail.com (J.V.C.); quynh.le@unsw.edu.au (Q.A.L.); \\ francisco.trujillo@unsw.edu.au (F.J.T.) \\ 2 National Institute of Animal Science, Rural Development Administration, Wanju 55365, Korea; moh@korea.kr \\ 3 Immunology and Allergy, The Children's Hospital at Westmead, Westmead, NSW 2145, Australia; \\ dianne.campbell1@health.nsw.gov.au (D.E.C.); sam.mehr@me.com (S.M.) \\ * Correspondence: alice.lee@unsw.edu.au; Tel.: +61-2-93854363
}

\section{check for}

updates

Citation: Sun, X.; Vivien Chua, J.; Le, Q.A.; Trujillo, F.J.; Oh, M.-H.;

Campbell, D.E.; Mehr, S.; Lee, N.A. A

Response Surface Methodology

(RSM) Approach for Optimizing the

Attenuation of Human IgE-Reactivity

to $\beta$-Lactoglobulin $(\beta-\mathrm{Lg})$ by

Hydrostatic High Pressure Processing.

Foods 2021, 10, 1741. https:/ /

doi.org/10.3390/foods10081741

Academic Editor: Philippe Delahaut

Received: 8 June 2021

Accepted: 23 July 2021

Published: 28 July 2021

Publisher's Note: MDPI stays neutral with regard to jurisdictional claims in published maps and institutional affiliations.

Copyright: (c) 2021 by the authors. Licensee MDPI, Basel, Switzerland. This article is an open access article distributed under the terms and conditions of the Creative Commons Attribution (CC BY) license (https:/ / creativecommons.org/licenses/by/ $4.0 /)$.
Abstract: The response surface methodology (RSM) and central composite design (CCD) technique were used to optimize the three key process parameters (i.e., pressure, temperature and holding time) of the high-hydrostatic-pressure (HHP) processing either standalone or combined with moderate thermal processing to modulate molecular structures of $\beta$-lactoglobulin $(\beta-\mathrm{Lg})$ and $\alpha$-lactalbumin ( $\alpha$-La) with reduced human IgE-reactivity. The RSM model derived for HHP-induced molecular changes of $\beta$-Lg determined immunochemically showed that temperature (temp), pressure $\left(\mathrm{p}^{2}\right)$ and the interaction between temperature and time $(t)$ had statistically significant effects $(p<0.05)$. The optimal condition defined as minimum ( $\beta$-Lg specific) IgG-binding derived from the model was $505 \mathrm{MPa}$ at $56^{\circ} \mathrm{C}$ with a holding time of $102 \mathrm{~min}\left(\mathrm{R}^{2}\right.$ of 0.81 and $p$-value of 0.01$)$. The validation carried at the optimal condition and its surrounding region showed that the model to be underestimating the $\beta$-Lg structure modification. The molecular change of $\beta$-Lg was directly correlated with HHP-induced dimerization in this study, which followed a quadratic equation. The $\beta$-Lg dimers also resulted in the undetectable human IgE-binding.

Keywords: $\beta$-lactoglobulin; $\alpha$-lactalbumin; high hydrostatic pressure processing; response surface models; rabbit IgG binding; human IgE-binding

\section{Introduction}

Cow's milk is one of the most common triggers of IgE-mediated food allergies in children and causes of food anaphylaxis deaths in young children [1]. One of the factors thought to contribute to the high prevalence in infants and children is their higher gastric $\mathrm{pH}$ of 3-4, forming unfavorable conditions for effective peptic hydrolysis when compared with an adult digestive system of $\mathrm{pH} 1.2-2$ [2]. $\beta$-Lactoglobulin $(\beta$-Lg) and $\alpha$-lactalbumin $(\alpha$-La) are the major allergens in whey protein for which $60-80 \%$ of cow's milk allergic patients react to $[3,4] . \beta-\mathrm{Lg}$ is highly stable to denaturation and resistant to proteolytic hydrolysis [5], whereas $\alpha$-La is more thermally resistant than $\beta$ - $\mathrm{Lg}[6,7]$. Due to slow or poor degradation, $\beta-\mathrm{Lg}$ is thought to be absorbed through the gut mucosa as an intact molecule or as substantial fragments $[2,8,9]$. These proposed mechanisms could potentially induce sensitization in high-risk individuals.

Food processing has the potential to alter the allergenic properties of proteins by either masking, destroying or disclosing allergenic epitopes through cleavage of linear structures or inducing conformational changes, or by improving the digestibility of proteins. High hydrostatic pressure (HHP) processing could modify the molecular structure and functional properties of proteins and other associated macromolecules without affecting 
color, flavor and micronutrient contents [10]. For example, dissociation of oligomeric proteins and multi-protein complexes could be induced by the moderately high pressure of 100-200 MPa [11], whereas pressures of 400-800 MPa are sufficient to induce denaturation of small monomeric proteins [12]. Pressures between 200 and $500 \mathrm{MPa}$ induce non-native monomers, dimers, trimers, and tetramers, while pressures $>500 \mathrm{MPa}$ induce higher molecular weight aggregates [13]. The typical pressure needed for the unfolding is around $500 \mathrm{MPa}$, however, it varies from protein to protein [14].

HHP induced immunoreactivity changes in food allergens have been demonstrated, but their reporting effects vary widely depending on the type of allergens, their antibodybinding epitopes and other extrinsic factors, such as processing conditions, single protein study vs mixed protein study, food matrix effects and characteristics of antibodies used for determining immunoreactivity. For example, the high pressure-induced conformational changes in the pork batter's protein with the alteration of some epitope structures were reported [15]. In this study, the HHP at $600 \mathrm{MPa}$ effectively modified the IgE immunoreactivity of the proteins in the sausage batter. The almond milk treated with high-pressure processing also showed complete elimination of conformation epitope and partial effects on linear epitopes [16]. The effect of HHP on $\beta$ - Lg was also reported, which claimed an increased $\beta-\mathrm{Lg}$ immunoreactivity in whey, sweet whey and raw skim milk (200-600 MPa, $\left.25-68{ }^{\circ} \mathrm{C}\right)$ [17].

Amongst structurally similar allergens, the effects of HHP could vary markedly. Of six nuts (pistachio, cashew, peanut, hazelnut, almond, and chestnut) treated with HHP (300-600 MPa, $20^{\circ} \mathrm{C}, 20 \mathrm{~min}$ ), only the immunoreactivities of pistachio, cashew, peanut and chestnut were altered [18]. The HHP-resistant property of almond allergens was also reported by Li et al. [19]. Even the same allergen could respond differently in different HHP studies, and this could be due to the experimental conditions as well as HHP equipment used. For example, the apple allergens, Mal d 1 and Mal $\mathrm{d} 1$ responded to HHP by reducing their immunoreactivities in one study [20] and yet no effects were reported in another study [21]. Also, HHP resistant nature of fish allergens (Gad m 1 and largemouth bass) were reported with limited influence on their protein structures and immunoreactivities [22,23].

As a result of HHP-induced molecular changes, HHP also enhanced the digestibility of whey protein, which subsequently generates peptides that improve glutathione status in CFTR-deficient lung epithelial cells [24]. Employing high-pressure pretreatment for destabilizing milk proteins has been shown to enhance their susceptibility to enzymatic hydrolysis [24-29]. The proteolytic susceptibility of $\beta$ - $\mathrm{Lg}$ increased 60 - to 80-fold in the pressure range of 0.1-250 MPa [30]. Pressures ranging from 350 to $600 \mathrm{MPa}$ dramatically increase the susceptibility of $\beta$-Lg to hydrolysis by pepsin, trypsin, chymotrypsin, pronase and thermolysin [31].

The HHP-enzymatic hydrolysis (EH) approach also improved the rate of hydrolysis at a pressure below $400 \mathrm{MPa}$ [27,31-35]. HHP-EH induced bioactive peptides are another innovation. In comparison to $\mathrm{EH}$, the HHP-EH process that combines pretreated protein hydrolysis with instantaneous pressurization and hydrolysis alters the peptide profiles in the hydrolysate. The process could also form novel peptides with increasing yield $[29,36,37]$. For example, by using chymotrypsin [36] and trypsin [29], HHP pretreated $\beta$-Lg marked by higher hydrophobicity. An elevation in bioactivity such as the antioxidant capacity of HHP-EH-generated peptides was also observed [35]. This is because HHP-EH generates higher low molecular weight peptides $(<10 \mathrm{kDa})$ with lower immunoreactivity and higher digestibility [31,38].

Several limitations/drawbacks of HHP such as inactivation of enzymes and protein aggregation resulting from decreased protein solubility were also noted. A decreased hydrolysis by the inactivation of enzymes at elevated pressure could occur [27,37]. Protein aggregation also can arise during pressurization and decompression [39]. It has been suggested that hydrolysis should be implemented immediately after the HHP treatment to avoid the loss of susceptibility of HHP-treated protein to proteolysis over time [28]. Yet the long-term stability of HHP-treated proteins has not been explored. 
As shown above, studies have shown the potential of HHP processing to induce molecular changes in protein with modified immunoreactivity, improved hydrolysis and digestibility, yet the optimum HHP processing conditions have not been modeled for whey protein targeting molecular changes with reduced (human) IgE reactivity. Therefore, in this study, the effects of three key process variables of HHP namely pressure, temperature and holding time were evaluated using a central composite design and modeled using the response surface methodology (RSM). The study determined optimum processing conditions defined as low IgG- and IgE-binding for whey protein allergens, $\beta$ - $\mathrm{Lg}$ and $\alpha$-La. Consequently, the correlation between rabbit IgG and human IgE-based immunoreactivity and dimerization was also investigated.

\section{Materials and Methods}

\subsection{Materials}

Whey protein and skim milk were prepared from raw milk, which was collected and delivered from the Lidcombe laboratory of Parmalat (Sydney, Australia). $\beta$ - Lg A and $\beta-\operatorname{Lg} B$ from bovine milk, $\alpha$-La from bovine milk, sodium dodecyl sulfate (SDS), 2-mercaptoethanol, goat anti-rabbit IgG-horseradish peroxidase (IgG-HRP), 3,3',5,5'-Tetramethylbenzidine (TMB), Tween 20 (polyoxyethylene sorbitan monolaurate), sodium acetate $\left(\mathrm{CH}_{3} \mathrm{COONa}\right)$, betacyclodextrin and urea hydrogen peroxide, dimethylsulfoxide (DMSO)- $99.9 \%$ molecular biology grade, sodium periodate, horseradish peroxidase (HRP), Bicinchoninic protein assay kit (BCA-1) containing bicinchoninic acid, sodium carbonate, sodium tartarate, sodium bicarbonate in $0.1 \mathrm{M} \mathrm{NaOH}$ ( $\mathrm{pH} 11.25)$, copper (II) sulfate pentahydrate $4 \%(w / v)$ solution and a protein standard (i.e., bovine serum albumin(BSA)) with a concentration of $1.0 \mathrm{mg} \mathrm{mL}^{-1}$ were purchased from Sigma-Aldrich (St. Louis, MO, USA). Precision Plus Protein $^{\mathrm{TM}}$ Prestained Standards $\left(\right.$ BioRad $^{\circledR}$, Hercules, CA, USA) ranging from $2 \mathrm{kDa}$ to $250 \mathrm{kDa}$ (161-0377), 40\% acrylamide/bis solution (37.5:1) (161-0148), 2X Laemmli sample buffer (161-0737), 10x tris/glycine/SDS running buffer (161-0772), Tris (161-0719) were obtained from BioRad. Sodium chloride $(\mathrm{NaCl})$, sodium hydrogen orthophosphate $\left(\mathrm{NaH}_{2} \mathrm{PO}_{4}\right)$, disodium hydrogen orthophosphate $\left(\mathrm{Na}_{2} \mathrm{HPO}_{4}\right)$, sodium bicarbonate $\left(\mathrm{NaHCO}_{3}\right)$, sodium carbonate $\left(\mathrm{Na}_{2} \mathrm{CO}_{3}\right)$, methanol, were purchased from Ajax Finechem (Seven Hills, NSW, Australia). Coomassie Brilliant Blue R-250 was purchased from Fluka (Loughborough, UK). Acetic acid glacial was from the Rhone Poulenc Laboratory Products (Clayton, VIC, Australia). $\mathrm{NaH}_{2} \mathrm{PO}_{4} \cdot 2 \mathrm{H}_{2} \mathrm{O}$ was purchased from $\mathrm{BDH}$ Chemicals (Australia) Pty Ltd. (Port Fairy, VIC, Australia). Maxisorp polystyrene 96-well microwell plates were supplied by Nunc (Roskilde, Denmark).

\subsection{Instrument}

A Mini Protean Tetra Cell, power pack HC was purchased from BioRad. Microcentrifuge tubes were purchased from Eppendorf (Macquarie Park, Australia, state abbrev if appropriate, country). The SpectraMax M2, multi-detection microplate reader and SoftMax analysis software were from Molecular Devices (Sunnyvale, CA, USA). The pH Meter was supplied by TPS Pty Ltd. (Brisbane, Australia). A ChemiDoc MP system from BioRad was used for gel image analysis and dimerization semi-qualitification. A Stansted Food Processor S-FL-850-09-W was purchased from Stasted Fluid Power Ltd. (Harlow, Essex, UK). A Lauda Proline RP-890 thermostatic bath/circulator was purchased from LAUDA-Brinkmann, LP (Delran, NJ, USA).

\subsection{HHP Treatments}

$\beta$ - $\mathrm{Lg}$ and $\alpha$-La solutions at $300 \mu \mathrm{g} \mathrm{mL} \mathrm{L}^{-1}$ were added to screw-capped cryogenic tubes and the tubes were vacuum-sealed in the polyethylene bags. The HHP treatment was then performed using the Stansted S-FL-850-09-W Food Processor coupled with a thermostatic bath/circulator for the temperature control operated at conditions as listed in Table 1. The rates of pressurization and decompression were $200 \mathrm{MPa}$ per min and the pressure-transmitting medium was $80 \%$ polypropylene glycol. Experiments were 
conducted in triplicates with PBS (0.1 M phosphate buffered saline, $\mathrm{pH}$ 7.4) and untreated protein solutions as the controls. After HHP treatment, samples were rested at $4{ }^{\circ} \mathrm{C}$ for 5 days before SDS-PAGE, ELISA, and BCA protein assay were performed. The 5-days resting period allowed the protein structures to come to stability and reduce deviation in subsequent measurements. The preliminary study of HHP conditions on the $\beta-\mathrm{Lg} \operatorname{IgG}$ binding was conducted to determine the appropriate ranges of key operating parameters involving pressure and holding time required for a factorial experimental design.

Table 1. Experimental range and levels of the independent variables.

\begin{tabular}{|c|c|c|c|c|c|c|}
\hline \multirow[b]{2}{*}{ Test Number } & \multicolumn{3}{|c|}{ Code-Level of Variables } & \multicolumn{3}{|c|}{ Experimental Level of Variables } \\
\hline & $\mathbf{x}_{1}$ & $\mathbf{x}_{2}$ & $\mathbf{x}_{3}$ & $\mathbf{P}(\mathbf{M P a})$ & $\mathrm{T}\left({ }^{\circ} \mathrm{C}\right)$ & $\mathrm{t}(\mathrm{min})$ \\
\hline 1 & -1 & -1 & -1 & 200 & 25 & 35 \\
\hline 2 & +1 & -1 & -1 & 600 & 25 & 35 \\
\hline 3 & -1 & +1 & -1 & 200 & 65 & 35 \\
\hline 4 & +1 & +1 & -1 & 600 & 65 & 35 \\
\hline 5 & -1 & -1 & +1 & 200 & 25 & 115 \\
\hline 6 & +1 & -1 & +1 & 600 & 25 & 115 \\
\hline 7 & -1 & +1 & +1 & 200 & 65 & 115 \\
\hline 8 & +1 & +1 & +1 & 600 & 65 & 115 \\
\hline 9 & -1.68 & 0 & 0 & 63.6 & 45 & 75 \\
\hline 10 & +1.68 & 0 & 0 & 736.4 & 45 & 75 \\
\hline 11 & 0 & -1.68 & 0 & 400 & 11.36 & 75 \\
\hline 12 & 0 & +1.68 & 0 & 400 & 78.64 & 75 \\
\hline 13 & 0 & 0 & -1.68 & 400 & 45 & 7.72 \\
\hline 14 & 0 & 0 & +1.68 & 400 & 45 & 142.28 \\
\hline 15 & 0 & 0 & 0 & 400 & 45 & 75 \\
\hline 16 & 0 & 0 & 0 & 400 & 45 & 75 \\
\hline 17 & 0 & 0 & 0 & 400 & 45 & 75 \\
\hline 18 & 0 & 0 & 0 & 400 & 45 & 75 \\
\hline 19 & 0 & 0 & 0 & 400 & 45 & 75 \\
\hline 20 & 0 & 0 & 0 & 400 & 45 & 75 \\
\hline
\end{tabular}

$\mathrm{x}_{1}=$ Pressure $(\mathrm{MPa}) ; \mathrm{x}_{2}=$ Temperature $\left({ }^{\circ} \mathrm{C}\right) ; \mathrm{x}_{3}=$ Time $(\mathrm{min})$.

\subsection{Experimental Design and Data Analysis}

A central composite design with three levels was performed to study the effects of the operating variables on the IgG binding and dimerization. As shown in Table 1, a CCD in the form of $3^{3}$ factorial design was used, in which three independent variables, pressure, temperature and holding time, were converted to respective dimensionless variables, $\mathrm{x}_{1}, \mathrm{x}_{2}$ and $x_{3}$, and coded at 3 levels: $-1,0,+1$. The parameter range was based on the preliminary study showing that the holding time does not need to be longer than $3 \mathrm{~h}$ because the pressure-induced changes occur rapidly, particularly at higher pressures. The temperature ranging from 11 to $78^{\circ} \mathrm{C}$ was chosen to cover from cooling to commercial pasteurization temperatures. The centre points were repeated 6 times to estimate the variability of the data. Each experiment was run in triplicates and the experimental order was randomized. The data obtained from the CCD was then fitted to a second-order polynomial regression equation (Equation (1)):

$$
\hat{y}=\hat{\beta_{0}}+\sum_{i=1}^{k} \hat{\beta_{i}} x_{i}+\sum_{i=1}^{k} \hat{\beta_{i i}} x_{i}^{2}+\sum_{i<j} \sum \hat{\beta_{i j}} x_{i} x_{j},
$$

\subsection{Determination of Optimal Operating Conditions and Validation of the Model}

When the contour plot displays ellipses or circles, the center of the system refers to a point of minimum responses called a saddle point. Those figures give useful information about the model showing general trends as explained by the fitted model but they may 
not represent the true behavior of the system. The minimum (or maximum) point occurs where the first derivative of the function equals zero.

$$
y=\hat{\beta_{0}}+\sum_{i=1}^{k} \hat{\beta_{i}} x_{i}+\sum_{i=1}^{k} \hat{\beta_{i i}} x_{i}^{2}+\sum_{i<j} \sum \hat{\beta_{i j}} x_{i} x_{j}+\varepsilon,
$$

The minimum point is found by calculating $\frac{\partial y}{\partial x_{1}}, \frac{\partial y}{\partial x_{2}}$, and $\frac{\partial y}{\partial x_{3}}$, and set to zero (Equation (2)):

$$
\begin{aligned}
& \frac{\partial y}{\partial x_{1}}=\beta_{1}+2 \beta_{4} x_{1}+\beta_{7} x_{2}+\beta_{8} x_{3}=0 \\
& \frac{\partial y}{\partial x_{2}}=\beta_{2}+2 \beta_{5} x_{2}+\beta_{7} x_{1}+\beta_{9} x_{3}=0 \\
& \frac{\partial y}{\partial x_{3}}=\beta_{3}+2 \beta_{6} x_{3}+\beta_{8} x_{1}+\beta_{9} x_{2}=0
\end{aligned}
$$

The minimum was calculated by solving the above equations. Validation was conducted by measuring IgG binding immunochemically and dimerization by polyacrylamide gel electrophoresis (SDS-PAGE) on the region surrounding the calculated minimum.

\subsection{The Bicinchoninic Acid (BCA) Protein Assay}

The protein contents were determined by a bicinchoninic acid kit (Sigma $\left.{ }^{\circledR}\right)$ using bovine serum albumin (BSA) as a standard. BSA was diluted with $50 \mathrm{mM}$ PBS (pH 7.4) to $0.8,0.6,0.4$ and $0.2 \mathrm{mg} \mathrm{mL}^{-1}$. Either BSA standards or sample protein $(25 \mu \mathrm{L})$, and streak reagent $(200 \mu \mathrm{L})$ were incubated in duplicate in the respective wells in a microtiter plate at $37^{\circ} \mathrm{C}$ for $30 \mathrm{~min}$. Absorbance was measured at $562 \mathrm{~nm}$ by a spectrometer (Molecular Devices SpectraMax M2).

\subsection{SDS-PAGE}

Protein samples $\left(0.3 \mathrm{mg} \mathrm{mL}^{-1}\right)$ were diluted with Laemli sample buffer $(1: 1 v / v)$, $20 \mu \mathrm{L} /$ well, were applied onto $15 \%$ polyacrylamide gel with $4 \%$ stacking gel. Before electrophoresis, protein samples were heated at $95^{\circ} \mathrm{C}$ for $5 \mathrm{~min}$. Precision Plus Protein ${ }^{\mathrm{TM}}$ Prestained Standards $\left(\right.$ BioRad $^{\circledR}$ ) ranging from $2 \mathrm{kDa}$ to $250 \mathrm{kDa}$ were used as molecular weight markers. Electrophoresis was conducted using a Mini Protean Tetra Cell (BioRad $\left.{ }^{\circledR}\right)$ at a constant voltage of $150 \mathrm{~V}$ until the sample dye reached the end of the gels. The gels were stained with Coomassie brilliant blue R-250. Finally, the gels were scanned and quantified with the ChemiDoc MP System (Bio-Rad $\left.{ }^{\circledR}\right)$.

\subsection{Enzyme-Linked Immuno-Sorbent Assay (ELISA)}

Rabbit anti- $\beta$-Lg, rabbit anti- $\alpha$-La and goat anti-whey protein were generated according to the approved UNSW Sydney animal ethics (ACEC11/2A). For immunization, $\beta-\mathrm{Lg}$ and $\alpha$-La were diluted to $0.25-1 \mathrm{mg} \mathrm{mL}^{-1}$ in $0.9 \% \mathrm{NaCl}$ and mixed with an equal volume of Titer Max Gold adjuvant. Antisera containing specific antibodies were collected from New Zealand white rabbits (UNSW, Sydney, Australia) and goats (Monash University, Melbourne, Australia) following a strict immunization regime [40]. The IgG antibodies were purified from the sera using protein A affinity chromatography.

Two ELISAs each specific to $\beta$ - $\operatorname{Lg}$ and $\alpha$-La were developed and optimized. In this study, the antibody binding (\%) measured by the ELISAs was used to determine the relative molecular changes induced by the HHP-thermal processing. In brief, $\beta$-Lg and $\alpha$-La stock solutions at $10 \mathrm{mg} \mathrm{mL}^{-1}$ were prepared in phosphate-buffered saline (PBS, $\mathrm{pH}$ 7.4). Capture antibodies (anti- $\beta$-Lg antibody or anti- $\alpha$-La antibody at $10 \mu \mathrm{g} \mathrm{mL}^{-1}$ in carbonate buffer, $\mathrm{pH}$ 9.6) were coated on a microtiter plate by overnight incubation. After washing with $0.05 \%$ Tween 20 in water, the plates were incubated for $1 \mathrm{~h}$ with $1 \%$ soybean protein in PBS ( $50 \mathrm{mM}$ phosphate buffer- $0.9 \%$ sodium chloride). The microtitre plates were then washed at least three times with $0.05 \%$ Tween 20 in water. Standard solutions (or calibration solutions) of whey protein were prepared by 2 -fold dilutions with the initial concentrations 
of 240 and $200 \mu \mathrm{g} \mathrm{L}{ }^{-1}$, for $\beta$-Lg and $\alpha$-La respectively. The plate was incubated for $30 \mathrm{~min}$ on a rotary shaker. After washing with $0.05 \%$ Tween 20 in water, a detection antibody (goat anti-whey protein antibody) was added to respective wells and incubated for $30 \mathrm{~min}$. An anti-goat IgG antibody conjugated with horseradish peroxidase solution prepared in $1 \%$ bovine serum albumin (BSA) containing $0.05 \%$ Tween 20 in PBS was incubated for $30 \mathrm{~min}$ after unbound detection antibody was removed. The chromogenic substrate solution containing hydrogen peroxide and $3,3^{\prime} 4,4^{\prime}$-tetramethylbenzidine was incubated for $20 \mathrm{~min}$ after the final washing to allow for color development. The color reaction was stopped with $0.125 \mathrm{M}$ sulfuric acid. The absorbance was measured at $450 \mathrm{~nm}$ using a SpectraMax M2 microplate reader (Molecular Devices). Immunoreactivity (defined as $\%$ relative IgG-binding) was calculated from the calibration curve of untreated protein." IgG-binding (\%) was calculated using the following expression:

$$
\operatorname{IgG}-\text { Binding }(\%)=\frac{\text { Detected concentration of treated sample }}{\text { Concentration of untreated sample }(\text { control })} \times 100,
$$

\subsection{Spectral Measurements}

Circular dichroism (CD) spectra of HHP-thermal processed $\beta$-Lg at $0.1 \mathrm{mg} \mathrm{mL}^{-1}$ in $0.03 \mathrm{M}$ phosphate buffer with $0.3 \% \mathrm{NaCl}$ (pH 7.2) were recorded by a Chirascan ${ }^{\mathrm{TM}}$-plus $\mathrm{CD}$ Spectrometer (Applied Photophysics, Leatherhead, Surrey, UK), equipped with a Peltier temperature controller thermalstated at $25^{\circ} \mathrm{C}$. Sample cell paths were set for $0.5 \mathrm{~mm}$ (quartz cuvette), with a spectral resolution of $0.5 \mathrm{~nm}$ and averaging time of $0.5 \mathrm{~s}$.

Fluorescence spectra were recorded using a Cary Eclipse fluorescence spectrometer (Agilent Technologies, Santa Clara, CA, USA at $25^{\circ} \mathrm{C}$. Protein solutions $(0.1 \mathrm{mg} / \mathrm{mL})$ were excited at $290 \mathrm{~nm}$, and the emission was automatically recorded at right angles to the excitation with a 5-nm bandwidth in the range 300-400 $\mathrm{nm}$.

\subsection{Dot Blotting with Rabbit IgG and Human IgE}

Seven serum samples from milk allergic patients with the confirmed clinical diagnosis of IgE-mediated milk allergy were provided by the Children's Hospital at Westmead (Sydney, Australia) with human ethics approval \#LNR/14/SCHN/516. All individuals ( 2 females and 5 males) had had a clinical reaction to cow's milk and positive ssIgE. Milkspecific IgE ranged from 0.67 to greater than $100 \mathrm{kU} / \mathrm{L}$ (median 7.05). Six out of the 7 had a positive ssIgE within 12 months of their last reaction. Only one child (Patient 7), who had had anaphylaxis to cow's milk (as their last reaction), but their ssIgE was done 3 years before their reaction and remained cow milk allergic at their last evaluation. Four individuals had a positive skin test to cow's milk extract $>3 \mathrm{~mm}$. These samples were screened for the component-specific IgE by immunoblots (data not shown). The serum IgEs were reacted to one or more of the following milk components: $\beta$-Lg, $\alpha$-La, BSA, IgG and casein. Two serum samples showing distinct $\operatorname{IgE}$ binding to $\beta$-Lg and $\alpha$-La were selected for our study. The control serum was from a healthy volunteer.

Five HHP-thermal treated $\beta$ - $\mathrm{Lg}$ with minimum IgG-responses were selected to assess their human IgE immunoreactivity as an indication for potential allergenic potential. These were; $600 \mathrm{MPa}-25{ }^{\circ} \mathrm{C}-115 \mathrm{~min}, 80{ }^{\circ} \mathrm{C}-75 \mathrm{~min}, 600 \mathrm{MPa}-65{ }^{\circ} \mathrm{C}-35 \mathrm{~min}, 400 \mathrm{MPa}-45{ }^{\circ} \mathrm{C}-$ $142.28 \mathrm{~min}$ and $400 \mathrm{MPa}-78^{\circ} \mathrm{C}-75 \mathrm{~min}$. Immunoblots were prepared by loading $2 \mu \mathrm{L}$ of $0.3 \mathrm{mg} / \mathrm{mL} \beta-\mathrm{Lg}$ solution from each treatment in triplicates on $0.45 \mu \mathrm{m}$ nitrocellulose membranes $\left(\operatorname{BioRad}^{\circledR}\right)$. The membrane was air-dried then blocking overnight with $1 \%$ soybean protein in PBS buffer. After washing, each blot was incubated with the selected rabbit IgG antibody diluted 1:2000 (for IgG) or patient serum in 1:20 in blocking solution overnight at room temperature with continuous shaking. The serum sample was selected based on its specificity to $\beta-\mathrm{Lg}$ in the screening. Serum from a nonallergic individual was used as a control. The blots were then vigorously washed thrice with PBS with $0.05 \%$ Tween 20, followed by incubating with mouse anti-human IgE Fc-HRP (Southern Biotech ${ }^{\circledR}$, Birmingham, AL, USA) for $1 \mathrm{~h}$ at room temperature. After washing, the signals were 
developed with SuperSignal ${ }^{\mathrm{TM}}$ West Dura Extended Duration Substrate (ThermoFisher Scientific ${ }^{\circledR}$, Waltham, MA, USA) and read by the ChemiDoc MP System (Bio-Rad ${ }^{\circledR}$ ).

\subsection{Statistical Analysis}

All the data were analyzed for statistical significance by $\mathrm{t}$-test, one-way ANOVA followed by Tukey's multiple comparisons test and 3-way-ANOVA with $\alpha=0.05$, using GraphPad Prism (GraphPad Software, LLC, San Diego, CA, USA) and Matlab (The MathWorks, Inc., xperiments were performed in triplicates and data were expressed as mean $\pm \mathrm{SD}$.

\section{Results and Discussion}

\subsection{Preliminary Study of Pressure, Holding Time and IgG Binding}

Before the HHP experiments were conducted, the protein concentration (i.e., $300 \mu \mathrm{g} \mathrm{mL}^{-1}$ ) was optimized for the HHP experiments to ensure the protein solubility was maintained and concentration was sufficient for the subsequent molecular analysis. At higher concentrations, protein aggregation was observed after the HHP in some samples and during the cold storage, which impacted the molecular analysis. The preliminary study of HHP parameters, pressure and holding time on the IgG-binding activity of $\beta$-Lg were conducted to determine the appropriate ranges of key operating parameters involving pressure and holding time required for a factorial experimental design.

Three pressures $(200,400$ and $600 \mathrm{MPa})$ were selected to determine the working pressure range. The holding time ranged from 0-120 min for $400 \mathrm{MPa}$ and $600 \mathrm{MPa}$ and 0-180 min for $200 \mathrm{MPa}$. All the experiments were conducted at ambient temperature $\left(25^{\circ} \mathrm{C}\right)$. The results of preliminary study are shown in Figure 1. All the samples were evaluated by ELISA and SDS-PAGE for processing effects. The SDS-PAGE revealed dimerization of $\beta$-Lg as a distinct band at $37 \mathrm{kDa}$. Toggling between monomeric at $18 \mathrm{kDa}$ and dimeric structures at $37 \mathrm{kDa}$ in SDS-PAGE was more visible at $600 \mathrm{MPa}$ than $400 \mathrm{~Pa}$. The degree of $\beta$-Lg dimerization was influenced by the holding time. The IgG binding was significantly reduced from 0-30 min at $400 \mathrm{MPa}$ and $600 \mathrm{MPa}$. The effects were then diminished after 30 min with \% IgG binding of remining at $25 \%$. A gradual reduction in \% IgG bining at $200 \mathrm{MPa}$ with increasing holding time was observed. Notably the standard deviation of $\%$ IgG binding at $200 \mathrm{Mpa}$ was greater than those at higher pressures.
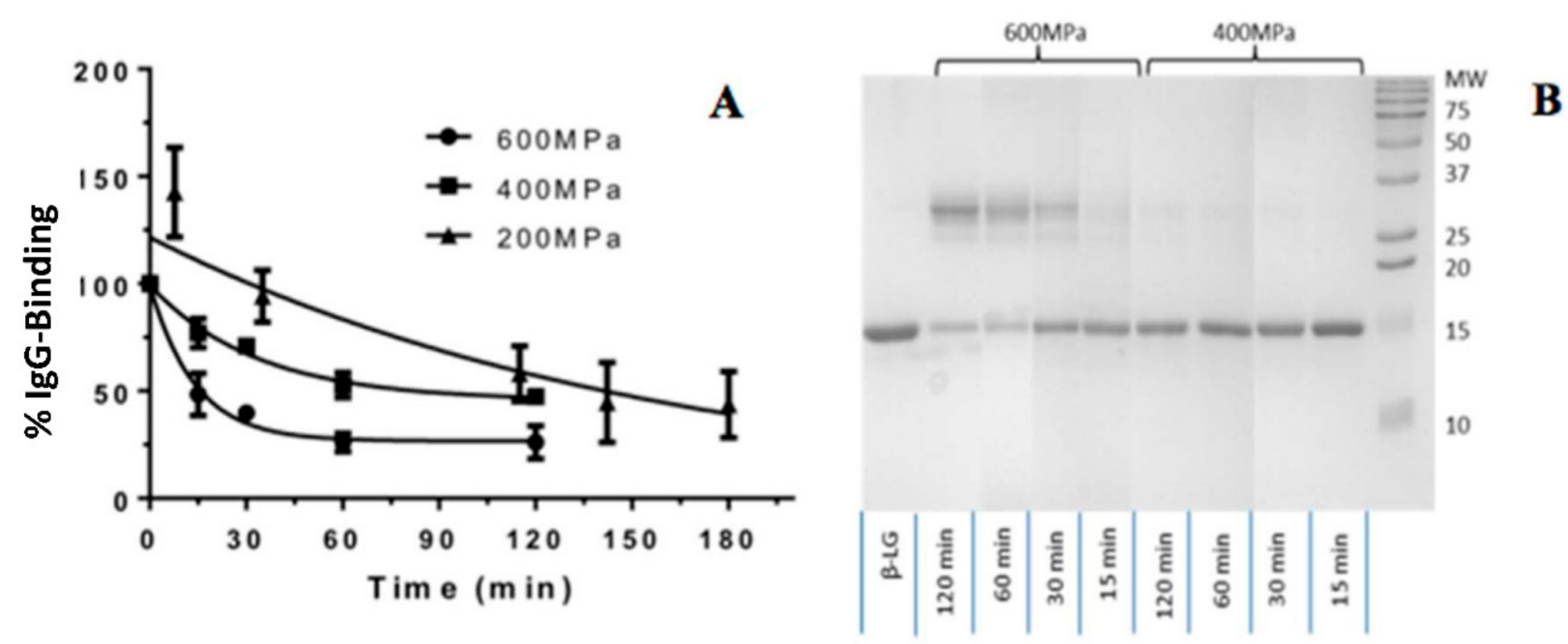

Figure 1. Preliminary study of IgG binding of HHP induced $\beta-\operatorname{Lg}(\mathbf{A})$ and SDS-PAGE of the protein profile of HHP induced protein modification $(\mathbf{B})$. 


\subsection{Effects of Process Variables on the Molecular Changes of $\beta$-Lactoglobulin Determined by IgG Binding}

An antibody-antigen interaction is a specific phenomenon relying on an antibody's ability to specifically bind to its antigen. Based on this, the HHP induced relative molecular changes of $\beta-\mathrm{Lg}$ with three processing variables (pressure, temperature and holding times) were determined by the IgG-reactivity. Before the ELISA, all the samples before and after the treatment were analyzed for protein concentration to ensure there was no loss of protein due to non-specific adsorption to the vial or aggregation and precipitation.

The \% IgG-binding of 15 processing conditions are illustrated in Figure 2. The summary of one-way ANOVA and Tukey's multiple comparisons test is shown in Supplementary Table S1. As in the preliminary study, lower pressures tended to induce variable $\%$ IgG binding with greater deviations (20-42.1\%). The apparent anomalous increase in larger standard deviations were probably due to the large structural heterogeneity present in the molecular transition state. In Figure 2, 15 treatment samples were devided into two categories $(a$ and $b$ ) based on their IgG binding activity (mean \pm SD). Treatments with the same letters were statistically insignificant.

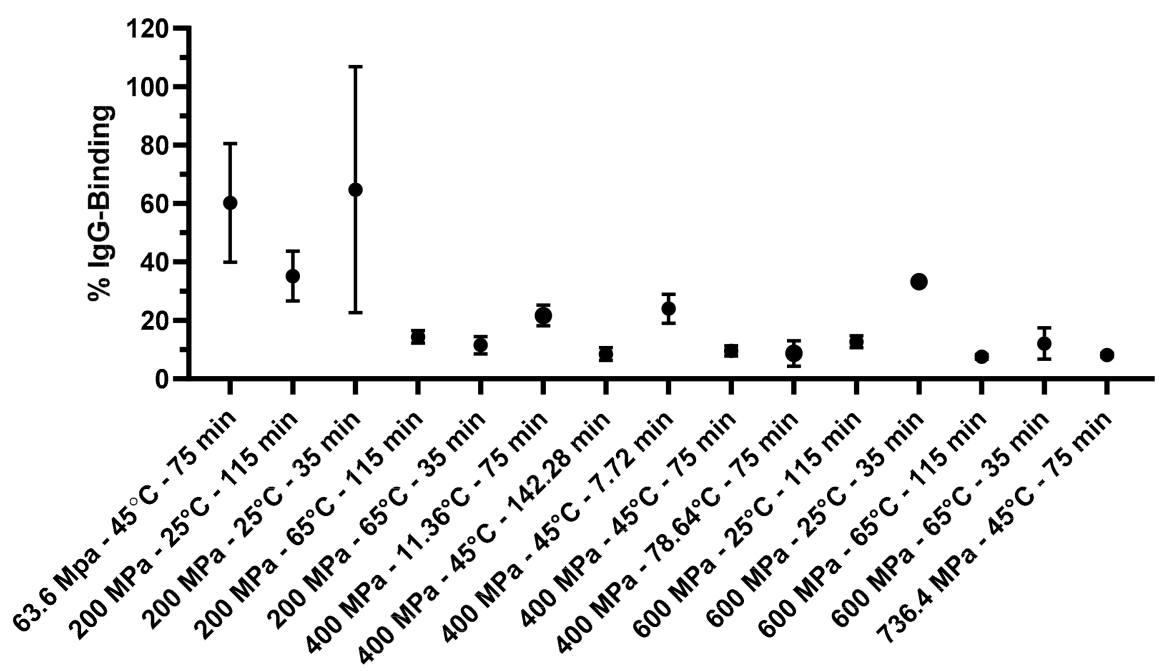

Figure 2. The \%IgG binding of HHP treated $\beta$-Lg at different HHP conditions.

The treatments conducted at $400 \mathrm{MPa}$ and above reduced the relative \% IgG binding to less than $25 \%$ of the untreated $\beta$ - Lg. The lowest IgG binding achieved in this system was $7.5 \%$ when $\beta$ - $\mathrm{Lg}$ was treated at $600 \mathrm{MPa}, 65^{\circ} \mathrm{C}$ for $115 \mathrm{~min}$. High pressure alone was less effective in reducing $\operatorname{IgG}$ binding of $\beta-\mathrm{Lg}$ than when high pressure was combined with moderate thermal treatment. Generally, raising treatment temperature decreased the IgG binding in all the combinations of pressure and holding time The effect of temperature was particularly noticeable at a holding time of $35 \mathrm{~min}$, when the temperature was increased from 25 to $65^{\circ} \mathrm{C}$, showing an average decrease by $53.3 \%$ and $21.2 \%$ at $200 \mathrm{MPa}$, and $600 \mathrm{MPa}$ respectively. At a longer holding time of $115 \mathrm{~min}$, however, increasing temperature from 25 to $65^{\circ} \mathrm{C}$ reduced the IgG-binding only by $20.8 \%$ and $5.2 \%$ at $200 \mathrm{MPa}$, and $600 \mathrm{MPa}$ respectively.

Increasing pressure reduced IgG binding for all the temperature and time combinations. The IgG binding generally decreased with an increasing holding time. The effect of holding time was more evident at $25^{\circ} \mathrm{C}$; at a lower temperature, a longer holding time was needed to reduce the IgG binding. The treatment at $200 \mathrm{MPa}$ and $65^{\circ} \mathrm{C}$ did not show a further reduction in the IgG binding when the holding time was increased from 35 to 115 min (Figure 2). This indicated that the protein modification occurred more rapidly during the first few minutes of the treatment.

All the treatments except for that at a lower temperature and shorter holding time $\left(25^{\circ} \mathrm{C}\right.$ and $35 \mathrm{~min}$ ) or lower pressure and lower temperature (i.e., $200 \mathrm{MPa}$ and $25^{\circ} \mathrm{C}$ ) were able to reduce the IgG binding below $15 \%$. 
In this work, the IgG binding of $\beta$-Lg was greatly influenced by pressure and temperature indicating the susceptibility of $\beta-\mathrm{Lg}$ structure to high pressure. The molecular susceptibility of $\beta$-Lg to HHP was also supported by other studies [41,42]. For instance, the treatment at $600 \mathrm{MPa}$ and $50{ }^{\circ} \mathrm{C}$, for the selected times up to $64 \mathrm{~min}$, induced a conformation change of $\beta-\operatorname{Lg}$ [41]. Karamanova et al., [42] also claimed changes in $\beta$-Lg could start at pressures as low as $100 \mathrm{MPa}$. At $200 \mathrm{MPa}$, formations of $\beta$-Lg non-native monomers and dimers were observed. At pressures beyond $500 \mathrm{MPa}, \beta$-Lg denatures extensively and aggregates to form polymers. Likewise, longer treatment times increase HP-induced denaturation and aggregation [42]. In our study, formation of dimers was not observed until $400 \mathrm{MPa}$, possibly due to the low protein concentration (Figure 1).

\subsection{The CD and Intrinsic Fluorescence Analyses of $\beta$ - $\mathrm{Lg}$ Treated with Selected HHP Conditions}

In this study, the $C D$ and intrinsic fluorescence analyses were performed for five selected operating conditions with lower IgG-binding to analyze the secondary and tertiary protein structure modification (Figure 3). The low protein concentration used for the study $\left(300 \mu \mathrm{g} \mathrm{mL}^{-1}\right)$ was not ideal for the $\mathrm{CD}$ analysis, hence the quality of $\mathrm{CD}$ generated was not of high quality. Nevertheless, it was adequate to provide minimum information regarding the molecular changes.
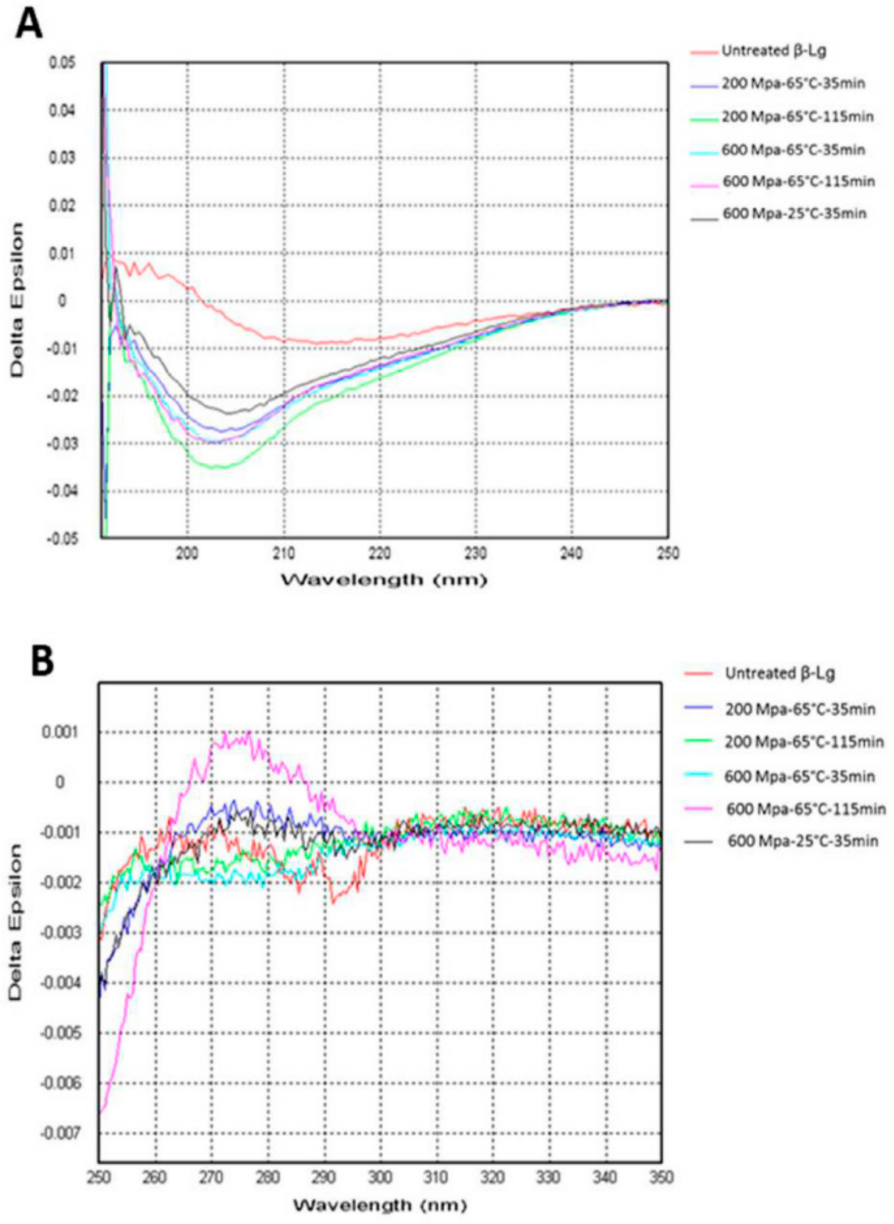

\section{C}

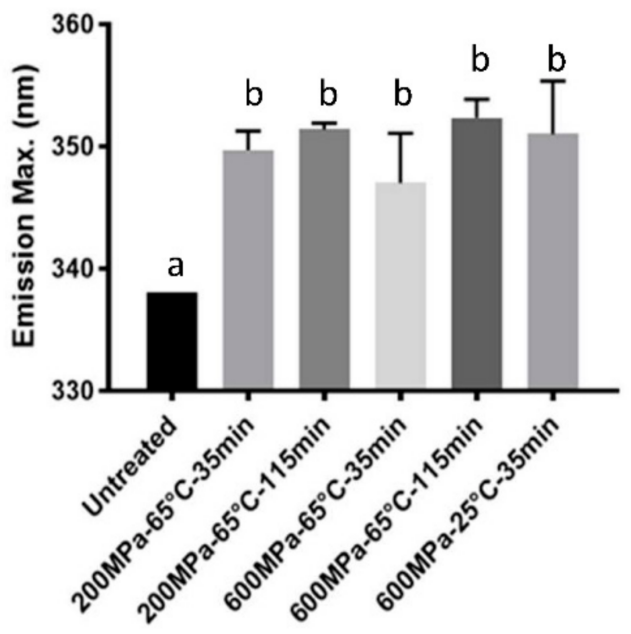

Figure 3. The CD spectra and fluorescence emission of untreated and HHP treated $\beta$-Lg: (A) Far-UV CD spectra, (B) near-UV CD spectra and (C) emission maxima of tryptophan fluorescence. Triplicate samples were used. Treatments with the same letters are statistically insignificant.

The increased intensity of the trough at $205 \mathrm{~nm}$ was found in the far-UV CD spectra indicating that the $\beta$-sheet content was essentially reduced (Figure 3 ). The shifting could 
be a consequence of the decreased ratio between the native monomers and induced dimers in the mixture (SDS-PAGE) and the loss of H-bonding involving the I-strands of $\beta-\operatorname{Lg}[43]$.

In the far-UV CD (Figure 3A), the trough, with a minimum at $216 \mathrm{~nm}$, shifted to lower wavelengths. The increased intensity of the trough at $205 \mathrm{~nm}$ in the spectra supported that the $\beta$-sheet content was essentially reduced by processing. The shifting could be a consequence of the decreased ratio of native monomers to dimers in the mixture and the loss of $\mathrm{H}$-bonding involving the I-strands of $\beta-\mathrm{Lg}$. In the near-UV CD spectra (Figure 3B), there was a reduction in the depth of two troughs at $286 \mathrm{~nm}$ and $293 \mathrm{~nm}$, suggesting that some ordered tertiary structure was no longer present in the proteins after HHP processing. Also, the spectra showed a significant and reproducible difference in the 250-270 nm regions, which corresponded to the disulfide bonds of $\mathrm{Cys}^{66}-\mathrm{Cys}^{160}$ and $\mathrm{Cys}{ }^{106}-\mathrm{Cys}^{119}$. The increasing intensity of the $250-270 \mathrm{~nm}$ region suggested the involvement of disulfide bonds of the processed $\beta-\mathrm{Lg}$ in the molecular changes.

Intrinsic fluorescence results (Figure 3C) were in the agreement with the CD spectra. The A right shift of emission spectra with a shift of $\lambda_{\max }$ from 338 to 347-352 were observed. There was a shift of $9-14.4 \mathrm{~nm}$ in the emission spectra, indicating the unfolding of $\beta-\mathrm{Lg}$ and the exposure of tryptophan residue as a result of tertiary structure changes. There was no significant difference between the degree of protein unfolding in the five processing conditions. However, it was apparent that the level of pressure applied to the protein influenced the degree of protein unfolding $(10.3 \pm 1.9 \mathrm{~nm}$ at $200 \mathrm{MPa}$ vs $13.6 \pm 0.7 \mathrm{~nm}$ at $600 \mathrm{MPa}$ ). The modification of protein structure evidenced by the CD and intrinsic fluorescence analyses, therefore, supported the changes observed with the IgG binding.

Our results of reduced IgG binding induced by HHP-thermal processing, however, opposed the results by Kleber et al. [17] and Meng et al. [44] who reported that the IgG binding of $\beta-\mathrm{Lg}$ increased with increasing pressure and holding time from 200 to $600 \mathrm{MPa}$ for up to $30 \mathrm{~min}$. They also found that increasing temperature from $30-68{ }^{\circ} \mathrm{C}$ resulted in increasing IgG reactivity. This difference could be due to the different sample matrix effects, for which Kleber et al. used milk while our results were based on purified $\beta$-Lg. Another possible reason would be the monoclonal antibody (IgY) they used could recognize linear epitopes in unfolded structures, resulting in the increased antibody binding. Whereas our polyclonal antibodies were raised against the native protein and were likely to be more sensitive to molecular changes from the native form (i.e., loss of IgG binding).

\subsection{CCD of IgG Binding of HHP Treated $\beta$-Lactoglobulin}

The response surface plots displayed the interaction effects of pressure and temperature at a constant holding time of $75 \mathrm{~min}$ (Figure $4 \mathrm{~A}$ ), pressure and holding time at a constant temperature of $45^{\circ} \mathrm{C}$ (Figure 4B), and temperature and holding time at $400 \mathrm{MPa}$ (experimental values are displayed as black points, Figure $4 \mathrm{C}$ ). Increasing pressure and temperature resulted in a minimum area of molecular changes determined by the $\operatorname{IgG}$ binding (Figure 4A). The experimental values on the minimum area were placed above the surface plot, indicating that the model may have underestimated the molecular changes. The experimental IgG binding did not decrease below 7.5\% despite the calculations suggesting otherwise. Likewise, the IgG binding area was lowest for the pressures between 400-600 MPa and holding times between 75-115 min (Figure 4B). Figure 3C showed the cumulative reduction of IgG binding when higher temperatures and longer holding times were combined (Figure 4C). 

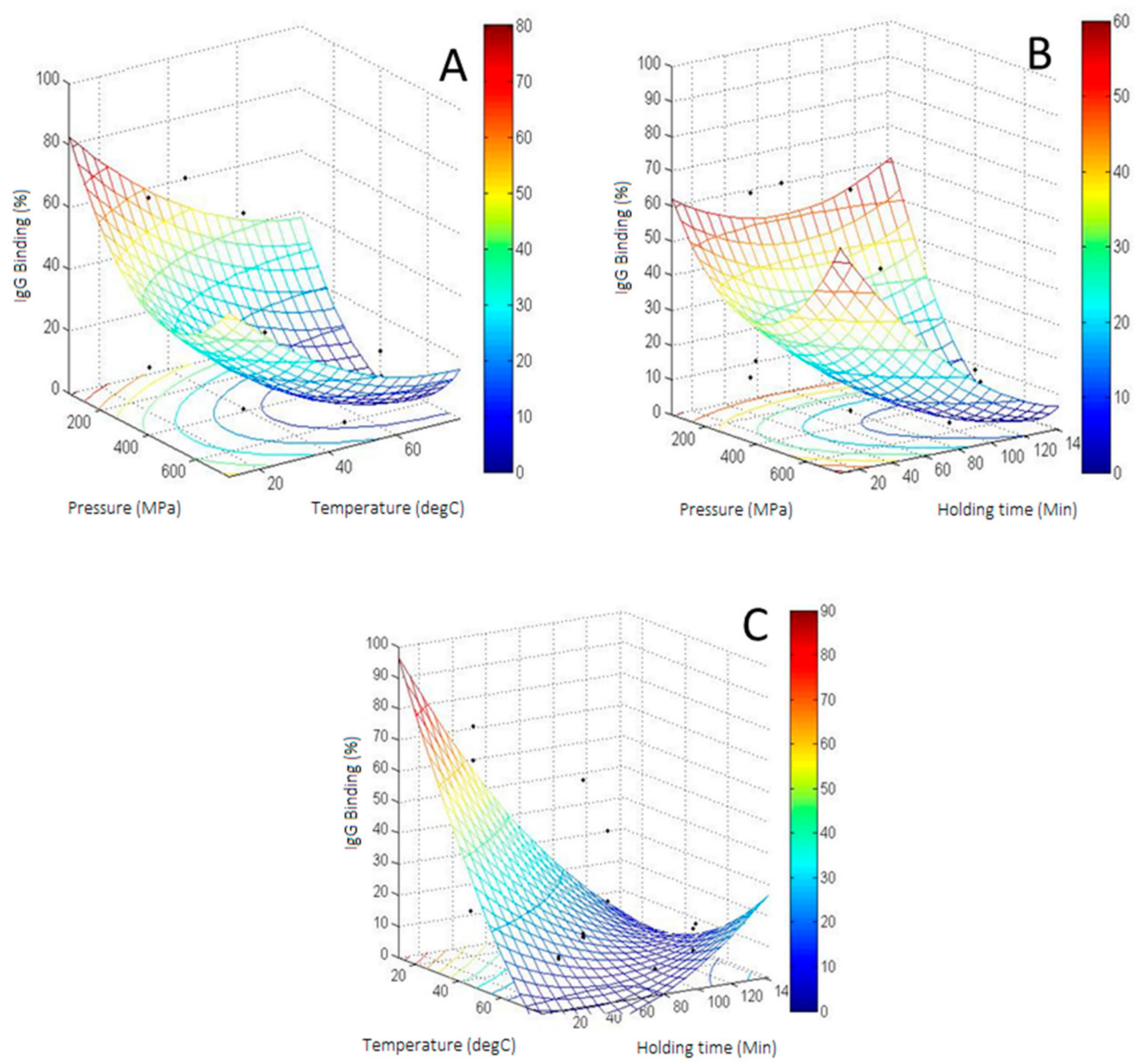

Figure 4. Surface plot of the combined effects of (A) pressure and temperature; (B) pressure and holding time; (C) temperature and holding time on the \% IgG binding of HHP-Heat treated $\beta$-Lg.

Average IgG binding data obtained experimentally was fitted into a second-order model yielding an $\mathrm{R}^{2}$ value of 0.81 . The model was able to explain over $81 \%$ of the variability in the $\beta-\mathrm{Lg} \operatorname{IgG}$ reactivity. The equation is shown below:

$$
\begin{gathered}
y=-0.2 x_{1}-2.495 x_{2}-0.956 x_{3}+0.000253 x_{1}^{2}+0.008 x_{2}^{2}+0.002 x_{3}^{2}+0.000167 x_{1} x_{2}-0.001 x_{1} x_{3}+0.014 x_{2} x_{3}+170.941, \\
\left(x_{1}=\text { Pressure }(M P a) ; x_{2}=\text { Temperature }\left({ }^{\circ} C\right) ; x_{3}=\text { Time }(\min )\right)
\end{gathered}
$$

The $R^{2}$ value can be considered as adequate for such biological response characterized by diverse protein transitions upon minimal or moderate processing conditions. Analysis of variance (3-way ANOVA) also showed that the model was significant with a $p$-value of 0.01 (Supplementary Table S2). The model showed the significant effect of temperature (linear effect), pressure (quadratic effect) and the interaction between temperature and time. Coefficients of the model for temperature, pressure ${ }^{2}$ and the temperature by time interaction were significant with $p$-values smaller than 0.05 (Supplementary Table S2). Other coefficients were insignificant, indicating only limited effects on the molecular changes.

\subsection{CCD of Dimerization of HHP Treated $\beta$ - $L g$}

The SDS-PAGE of HHP-thermal $\beta$-Lg, at the levels of variables listed in Table 1, under non-reduced conditions are shown in Figure 5D. The formation of non-native dimers $(\sim 30.4 \mathrm{kDa})$ from their monomers $(\sim 15.9 \mathrm{kDa})$ was obvious. HHP-thermal induced $\beta$-Lg dimer was quantified from SDS-PAGE using ChemiDoc MP system (Biorad). The \%Dimer and \%Monomer were calculated based on their band intensity. The degree of dimers formed was influenced by the treatment conditions. For example, no dimers were formed 
when $\beta$ - $\mathrm{Lg}$ was treated at $200 \mathrm{MPa}$ and $25^{\circ} \mathrm{C}$ for $35 \mathrm{~min}$. Small amounts of dimers $(<20 \%)$ were formed at low pressure and temperature, such as $200 \mathrm{MPa}, 25^{\circ} \mathrm{C}$ and $115 \mathrm{~min}$ and $63.6 \mathrm{MPa}, 45^{\circ} \mathrm{C}$ and $75 \mathrm{~min}$, while more than $50 \%$ of the native monomers converted to dimers in most other treatment conditions.
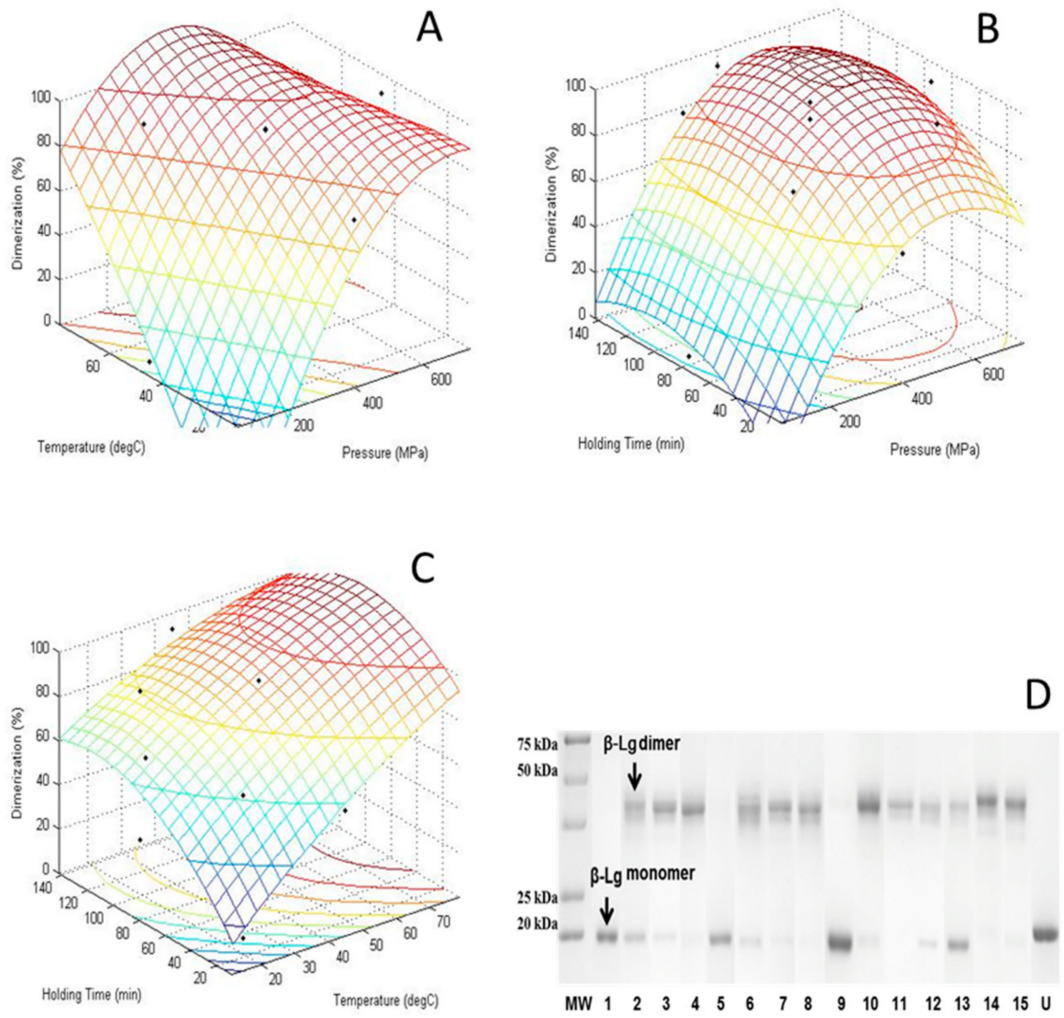

Figure 5. Surface plot of the combined effects of (A) pressure and temperature; (B) pressure and holding time; (C) temperature and holding time on the dimerization (\%) of HHP treated $\beta-\mathrm{Lg}$; (D) non-reducing SDS-PAGE analysis of HHP-Heat treated $\beta-\mathrm{Lg}$ ((1) $200 \mathrm{MPa}-25^{\circ} \mathrm{C}-35 \mathrm{~min},(2)$ $600 \mathrm{MPa}-25{ }^{\circ} \mathrm{C}-35 \mathrm{~min}$, (3) $200 \mathrm{MPa}-65{ }^{\circ} \mathrm{C}-35 \mathrm{~min},(4) 600 \mathrm{MPa}-65^{\circ} \mathrm{C}-35 \mathrm{~min}$, (5) $200 \mathrm{MPa}-25{ }^{\circ} \mathrm{C}-$ $115 \mathrm{~min},(6) 600 \mathrm{MPa}-25^{\circ} \mathrm{C}-115 \mathrm{~min},(7) 200 \mathrm{MPa}-65^{\circ} \mathrm{C}-115 \mathrm{~min},(8) 600 \mathrm{MPa}-65^{\circ} \mathrm{C}-115 \mathrm{~min},(9)$ 63.6 MPa-45 ${ }^{\circ} \mathrm{C}-75 \mathrm{~min},(10) 736.4 \mathrm{MPa}-45^{\circ} \mathrm{C}-75 \mathrm{~min}$, (11) $400 \mathrm{MPa}-11.36{ }^{\circ} \mathrm{C}-75 \mathrm{~min}$, (12) $400 \mathrm{MPa}-$ $78.64{ }^{\circ} \mathrm{C}-75 \mathrm{~min},(13) 400 \mathrm{MPa}-45^{\circ} \mathrm{C}-7.72 \mathrm{~min},(14) 400 \mathrm{MPa}-45^{\circ} \mathrm{C}-142.28 \mathrm{~min},(15) 400 \mathrm{MPa}-45^{\circ} \mathrm{C}-$ 75 min and (U) Untreated).

The formation of dimers from the native monomeric $\beta$ - $\operatorname{Lg}$ has been reported by [45]. According to Considine et al. [46], the application of pressure results in various events such as protein unfolding, exposure of internal free sulfhydryl groups, disulfide bond interchanges and aggregation. Upon depressurization, exposed groups could react with free S-H groups. Those groups may not return to their native forms before the protein refolds. Pressure may also induce differential charge distribution. Slight differences in charge distribution may cause two molecules to interact forming a stable dimer if conformational changes enable appropriate groups on the surface to interact with each other [45]. In our study, pressure above $400 \mathrm{MPa}$ induces more than $90 \%$ of dimerization. This is expected because the likelihood of two molecules interacting to form stable dimers increases at higher pressure and temperature.

A regression analysis (Supplementary Table S3) was carried out to fit the dimerization of HHP treated $\beta$-Lg as a function of the process variables, pressure, temperature and holding time. The model is described by the equation below: 


$$
\begin{gathered}
y=20.99 x_{1}+17.54 x_{2}+7.87 x_{3}-15.09 x_{1}^{2}-0.43 x_{2}^{2}-3.59 x_{3}^{2}-16.05 x_{1} x_{2}-2.37 x_{1} x_{3}-6.82 x_{2} x_{3}+92.72 \\
\left(x_{1}=\text { Pressure }(\mathrm{MPa}) ; x_{2}=\text { Temperature }\left({ }^{\circ} \mathrm{C}\right) ; x_{3}=\text { Time }(\min )\right)
\end{gathered}
$$

The significance of each coefficient was determined by the 3-way ANOVA (Supplementary Table S3). The variables with the largest effect on the dimerization were the linear terms of pressure and temperature, the quadratic term of pressure, and the interaction between pressure and temperature. The pressure and temperature had highly significant effects on dimerization $(p<0.001)$ while holding time had a less significant effect $(p=0.0506)$. The coefficient of determination $\left(\mathrm{R}^{2}\right)$ of the model was 0.93 showing a good fit.

Figure $5 \mathrm{~A}-\mathrm{C}$ shows the response surface plots of dimerization as a function of temperature and pressure at a constant holding time of $75 \mathrm{~min}$ (Figure 5A), a function of holding time and pressure at a constant temperature of $45^{\circ} \mathrm{C}$ (Figure 5B), and a function of holding time and temperature at constant pressure of $400 \mathrm{MPa}$ (Figure 5C). The dimerization increased as both pressure and temperature increased (Figure 5C). An increase in dimerization was mainly influenced by increasing temperature and/or pressure, while holding time had little influence (Figure 5B,C).

\subsection{Relationship between IgG Binding and Dimerization}

The relationship between IgG binding and dimerization of $\beta-\mathrm{Lg}$ is illustrated in Figure 6. The dimerization resulted in lower IgG binding, which followed the quadratic equation in Figure 4. The equation showed a good correlation between the reduced IgG binding and the increased dimerization, exhibiting an $\mathrm{R}^{2}$ value of 0.95 . There was one point that showed large deviations in both directions. The processing condition of the point was at the lower level for the three process variables, at $200 \mathrm{MPa}, 25^{\circ} \mathrm{C}$ and $35 \mathrm{~min}$ of holding time. At this intermediate condition, it is expected that the protein undergoes diverse transitional states, hence showing a greater heterogeneity in the IgG binding. Transitional modification is not always consistent for every protein molecule and this exacerbates at the intermediate process conditions. The standard deviations of protein transition in the other treatments were within 5\%, indicating a more consistent and reproducible protein transition at those higher conditions. Figure 5 shows two overlapping contour plots of dimerization (pink color) and IgG binding (blue color). The overlay area is displayed in white color by setting IgG binding between $7.5-10 \%$ and dimerization between $90-100 \%$. The overlapping region of low IgG binding (7.5-10\%) and high dimerization (90-100\%) occurs at a pressure between $400-600 \mathrm{MPa}$ and temperatures between $40-50{ }^{\circ} \mathrm{C}$ at a constant holding time of $75 \mathrm{~min}$. Reducing pressure to the range of 300-400 MPa would require a higher temperature between 50 to $65{ }^{\circ} \mathrm{C}$ to keep it within the overlapping region.

A

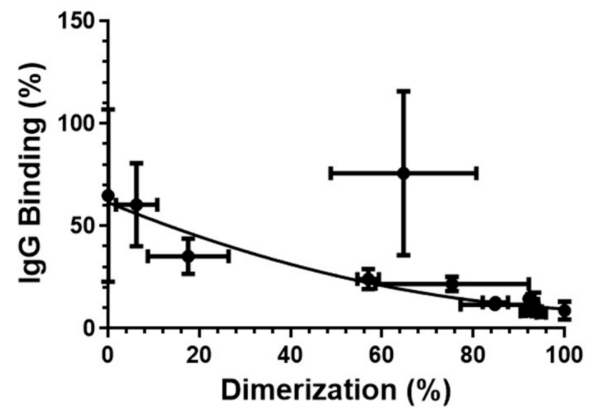

B

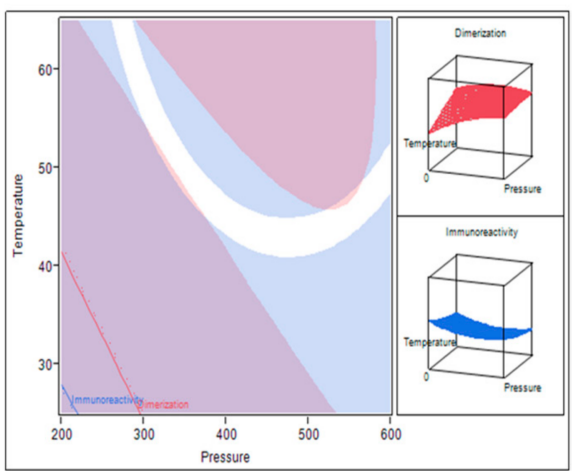

Figure 6. The plot of dimerization vs the $\%$ IgG-binding of $\beta$-Lg. (A) Equation: $y=61.48-0.9103 x$ $\left.+0.003909 x^{2}, R^{2}=0.9482\right)$ and (B) Overlay plot of \% IgG-binding and dimerization of $\beta$-Lg in the constraint setting (Blue area: \% Antigenicity > 10\%; Pink area: \% Dimerization $<90 \%$ ). 
Considering the immunogenic epitopes on $\beta-\mathrm{Lg}$, the coexistence of high dimerization and low IgG binding can be explained by either masking or modifying conformational epitope moieties upon dimerization that becomes less accessible to the antibody [47]. HHP, as a powerful process, generates folding conformational states of $\beta$ - Lg [48]. High pressure either as single processing or combined with thermal processing promotes transient modifications of the $\beta-\mathrm{Lg}$ structure at neutral $\mathrm{pH}$, inducing transient monomer to dimer, burying the previously exposed hydrophobic sites. The $\mathrm{CD}$ and instinct fluorescence measurements demonstrated the irreversible effects of high-pressure treatment on the secondary and tertiary structures of $\beta-\mathrm{Lg}$.

\subsection{Determination and Validation of Calculated Optimum Response}

The optimal conditions derived from the model were $505 \mathrm{MPa}$ of pressure; a temperature of $56{ }^{\circ} \mathrm{C}$ and a holding time of $102 \mathrm{~min}$. Under these conditions, the \% IgG binding (i.e., molecular changes) calculated with Equation (7) was 1.4\%. A supplementary experiment was carried at the optimal conditions and its surrounding region as a validation (Table 2). The experimental IgG binding remained between $20-35 \%$ with $70-85 \%$ of dimerization. The experimental results disagreed with the calculated values, suggesting that the model indeed underestimated the IgG-binding around the minimum area. Nevertheless, the correlation between $\operatorname{IgG}$ binding and dimerization displayed in Figure 5 statistically fits better than the equation generated by RSM when the exclusion of the point with high standard deviation was applied (columns 5 and 6 on Table 2).

Table 2. Model validations.

\begin{tabular}{|c|c|c|c|c|c|c|c|}
\hline & & Variables & & $\begin{array}{c}\text { \%IgG } \\
\text { Binding }\end{array}$ & Dimerization & $\begin{array}{l}\% \text { IgG } \\
\text { Binding }\end{array}$ & $\begin{array}{l}\% \text { IgG } \\
\text { Binding }\end{array}$ \\
\hline Test Number & P (MPa) & $\mathrm{T}\left({ }^{\circ} \mathrm{C}\right)$ & $t(\min )$ & Exp. Value & Exp. Value & Cal. Value ${ }^{a}$ & Cal. Value ${ }^{b}$ \\
\hline 1 & 505 & 56 & 102 & $21.4 \pm 6.4$ & 84.6 & 1.4 & 12.6 \\
\hline 2 & 505 & 51 & 102 & $27.2 \pm 0.5$ & 71.2 & 1.6 & 16.5 \\
\hline 3 & 505 & 61 & 102 & $29.2 \pm 0.6$ & 74.9 & 1.5 & 15.2 \\
\hline 4 & 455 & 56 & 102 & $19.4 \pm 1.8$ & 74.9 & 2.1 & 15.2 \\
\hline 5 & 555 & 56 & 102 & $32.6 \pm 7.3$ & 76.4 & 2.0 & 14.8 \\
\hline 6 & 505 & 56 & 92 & $34.5 \pm 8.6$ & 71.5 & 1.7 & 16.4 \\
\hline 7 & 505 & 56 & 112 & $27.4 \pm 12.5$ & 75.4 & 1.6 & 15.1 \\
\hline
\end{tabular}

${ }^{a}$ Calculated value using equation 3 from RSM. ${ }^{b}$ Calculated value using the equation from Figure $4 \mathrm{~A}$.

\subsection{Effects of Thermal and HHP Treatments on $\alpha$-La}

The HHP-thermal-induced $\alpha$-La IgG binding ranged from 52 to $144 \%$ compared to the untreated $\alpha$-La. The standard deviations were considerably large ranging from 8 to $83 \%$. Due to the large standard deviations, the ANOVA shows no significant effects in all of the tested process parameters (model $p$-value of 0.34) (Supplementary Table S4). With an $R^{2}$ value of 0.54 , the model did not correlate the IgG binding response with any of the process variables. The regression coefficients of most parameters were insignificant. Only the pressure was found to be significant with a $p$-value of 0.05 .

There were no aggregates detected in all the HHP treated, HHP-thermal combined and the thermal-only treated $\alpha$-La. The large standard deviation observed in this study was likely to be attributed to the reversible denaturation or refolding of $\alpha$-La molecule since $\alpha$-La had no free sulfhydryl groups for dimerization to occur readily [49-52]. As proteins undergo structural modification to new conformational states upon HHP-thermal processing, previously hidden linear or conformational epitopes could be revealed for IgG binding. The large standard deviations thus support this proposition as refolding occurs at a molecular level but does not replicate analogously across all molecules. Nevertheless, due to the random nature of $\alpha$ - $\operatorname{La}$ IgG binding, the fitted model and its related contour plots were disregarded. 


\subsection{Dot-Blotting with Rabbit IgG and Human IgE}

Roughly $60 \%$ of adverse reactions to cow's milk are related to IgE-mediated allergy and human IgE responses to cow's milk proteins are characterized by a diverse specificity and sensitivity [53-55]. Our pool of sera from the patients with the confirmed clinical diagnosis of IgE-mediated milk allergy also showed a diverse IgE-binding signature. Due to the limited number and supply of the available patient sera with specific binding to $\beta$-Lg and $\alpha$-La, only two serum samples each with distinct IgE binding to $\beta$ - $\mathrm{Lg}$ and $\alpha-\mathrm{La}$ were selected to determine the IgE-binding to HHP-treated proteins. Here, we compared the rabbit IgG-reactivity, as the relative molecular changes, to that of human IgE-reactivity.

As shown in Figure 7, all five treatments demonstrated a similar significant reduction in the rabbit IgG binding. The decreased rabbit IgG binding indicated that treatmentinduced protein structural modification through the disulfide bond and hydrophobic interchange between the proteins $[56,57]$ and dimerization (Figure 5) led to a loss of IgG conformational epitopes. Very promisingly, the treated $\beta$-Lg showed undetectable human IgE binding in the dot blots, showing the potential of using HHP-thermal processing to produce dairy-based products with lower IgE-reactivity. As aforementioned that milk allergic sera show diverse IgE binding profiles to different milk allergens, it is important to confirm the reduced IgE binding with more patient serum samples.

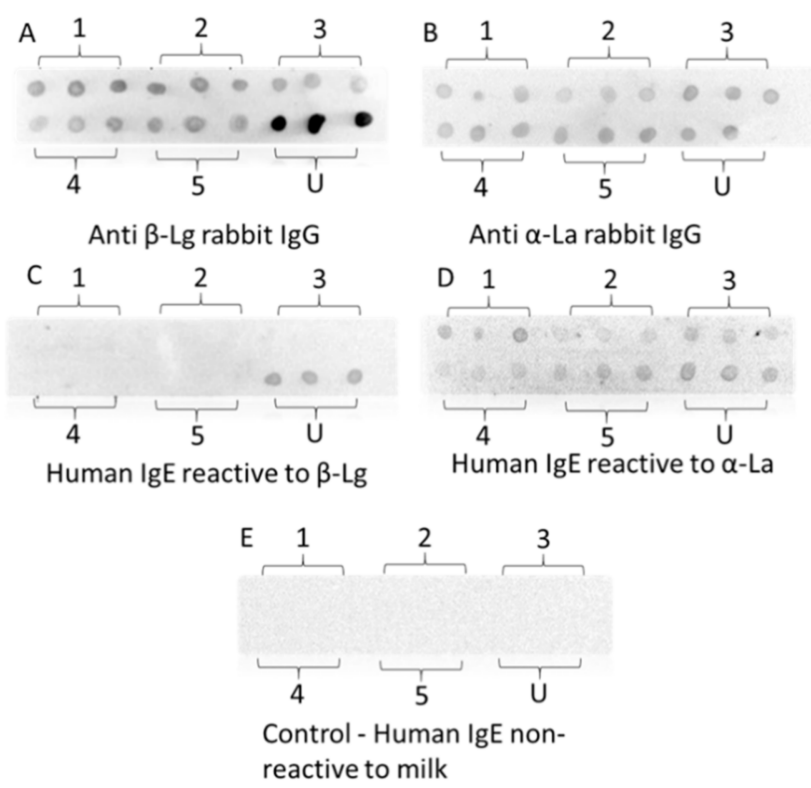

Figure 7. Dot blots of untreated and HHP-heat-processed $\beta$-Lg and $\alpha$-La with anti- $\beta$-Lg rabbit $\operatorname{IgG}(\mathbf{A})$, anti- $\alpha$-La rabbit $\operatorname{IgG}(\mathbf{B})$ and human $\operatorname{IgE}(\mathbf{C}, \mathbf{D})$. (E) Control dot bot with serum from a nonallergic individual. 1-6 represented different treatments: $1.600 \mathrm{MPa}-25^{\circ} \mathrm{C}-35 \mathrm{~min} ; 2.80{ }^{\circ} \mathrm{C}-75 \mathrm{~min}$; 3. $600 \mathrm{MPa}-65{ }^{\circ} \mathrm{C}-35 \mathrm{~min} ; 4.400 \mathrm{MPa}-45^{\circ} \mathrm{C}-142.28 \mathrm{~min} ; 5.400 \mathrm{MPa}-45^{\circ} \mathrm{C}-75 \mathrm{~min}$; U. Untreated.

On the other hand, there was an unnoticeable change in both rabbit IgG and human IgE binding for $\alpha$-La after the treatment at five different conditions. These results were consistent with some earlier studies which showed that $\alpha$-La is highly resistant to HHP due to the presence of four disulfide bonds in the ternary arrangement, creating structural rigidity $[46,57,58]$. Additionally, there are moderately weak hydrophobic interactions between unfolded $\alpha$-La resulting in high thermal resistance [59,60]. These findings consolidate the effects of HHP-thermal processing to be beneficial for producing hypoallergenic dairy products.

\section{Conclusions}

A response surface methodology with a central composite design was conducted to study the effects of pressure, temperature and holding time on the molecular changes as determined by the rabbit IgG binding and dimerization of $\beta-\mathrm{Lg}$, and $\alpha$-La. The model 
showed the significant effect of temperature, the square of pressure and the interaction between temperature and time, but it underpredicted the minimum value. The $\beta-\mathrm{Lg}$ dimerization is significantly affected by pressure, temperature, the square of pressure and the interaction between pressure and temperature. The ANOVA of $\alpha$-La IgG binding showed no or little significant effects of temperature, pressure or holding time, suggesting that $\alpha$-La as a single protein is more tolerable to high pressure This study revealed for the first time that $\beta$-Lg dimerization resulted in lower $\operatorname{IgG}$ binding which followed a quadratic equation with an $R^{2}$ value of 0.95 .

The RSM was shown to be an effective method to correlate and optimize the effects of the HHP process variables on biological responses. The methodology proved to be adequate for the design of a process yielding a significant molecular change with minimum IgE binding against $\beta$-Lg. The negligible residual IgE-reactivity of HHP treated $\beta-\mathrm{Lg}$ demonstrates a promising potential of high-pressure processing to lower the allergenic potential of whey-based products while adding value to its growing market. As only a limited number of milk allergic sera was used as a proof of IgE-binding, hypoallergenicity should be further confirmed with additional representative serum samples and other means such as basophil activation assay. Also, further study on more complex milk or whey matrices containing both $\beta$ - $\mathrm{Lg}$ and $\alpha$-La is needed to provide greater insights into how these molecules interact with each other and behave under high-pressure conditions.

Supplementary Materials: The following are available online at https:/ / www.mdpi.com/article/10 .3390 / foods10081741/s1, Table S1: One-way ANOVA analysis and Tukey's multiple comparisons test of IgG binding of $\beta$-Lg treated with 15 different HHP conditions. Only statically significant pairs are listed., Table S2: Three-way ANOVA analysis of CCD of IgG binding of HHP treated $\beta$-Lg., Table S3: The 3-way ANOVA of the response surface model of $\beta$-Lg dimerization. Table S4: Three-way ANOVA of CCD of IgG binding of HHP treated $\alpha$-La.

Author Contributions: Conceptualization, N.A.L.; methodology, X.S., J.V.C., N.A.L.; formal analysis, X.S., J.V.C., N.A.L.; investigation, X.S., J.V.C., N.A.L.; resources, N.A.L., D.E.C., S.M.; writing—original draft preparation, X.S., Q.A.L.; writing-review and editing, X.S., N.A.L., Q.A.L., F.J.T., D.E.C., S.M.; supervision, N.A.L.; project administration, N.A.L.; funding acquisition, N.A.L., M.-H.O. All authors have read and agreed to the published version of the manuscript.

Funding: This research was funded by the UNSW Major Research Equipment and Infrastructure Initiative (MREII), grant number RG094224 and Rural Development Administration, Republic of Korea, grant number PJ00932903.

Institutional Review Board Statement: The study was approved by the Sydney Children's Hospitals Network Human Research Ethics Committee of HREC reference number \#LNR/14/SCHN/516 and date of approval 19 November 2014, in accordance with the National Health and Medical ResearchCouncil's National Statement on Ethical Conduct in Human Research and CPMP/ICH Note for Guidance on Good Clinical Practice.

Informed Consent Statement: Informed consent was obtained from all subjects involved in the study.

Conflicts of Interest: The authors declare no conflict of interest.

\section{References}

1. Mullins, R.J.; Wainstein, B.K.; Barnes, E.H.; Liew, W.K.; Campbell, D.E. Increases in anaphylaxis fatalities in Australia from 1997 to 2013. Clin. Exp. Allergy 2016, 46, 1099-1110. [CrossRef]

2. Schmidt, D.; Meijer, R.; Slangen, C.; Van Beresteijn, E. Raising the $\mathrm{pH}$ of the pepsin-catalysed hydrolysis of bovine whey proteins increases the antigenicity of the hydrolysates. Clin. Exp. Allergy 1995, 25, 1007-1017. [CrossRef] [PubMed]

3. Mills, S.; Ross, R.; Hill, C.; Fitzgerald, G.; Stanton, C. Milk intelligence: Mining milk for bioactive substances associated with human health. Int. Dairy J. 2011, 21, 377-401. [CrossRef]

4. Fox, A.T.; Thomson, M. Adverse reactions to cows' milk. Paediatr. Child Health 2007, 17, 288-294. [CrossRef]

5. Breiteneder, H.; Mills, E.C. Molecular properties of food allergens. J. Allergy Clin. Immunol. 2005, 115, 14-23. [CrossRef]

6. Wal, J. Structure and function of milk allergens. Allergy 2001, 56, 35-38. [CrossRef]

7. Hinrichs, J.; Rademacher, B. Kinetics of combined thermal and pressure-induced whey protein denaturation in bovine skim milk. Int. Dairy J. 2005, 15, 315-323. [CrossRef] 
8. Maier, I.; Okun, V.M.; Pittner, F.; Lindner, W. Changes in peptic digestibility of bovine $\beta$-lactoglobulin as a result of food processing studied by capillary electrophoresis and immunochemical methods. J. Chromatogr. B. 2006, 841, 160-167. [CrossRef]

9. Metcalfe, D.D.; Astwood, J.D.; Townsend, R.; Sampson, H.A.; Taylor, S.L.; Fuchs, R.L. Assessment of the allergenic potential of foods derived from genetically engineered crop plants. Crit. Rev. Food Sci. Nutr. 1996, 36, 165-186. [CrossRef] [PubMed]

10. Mozhaev, V.V.; Heremans, K.; Frank, J.; Masson, P.; Balny, C. High pressure effects on protein structure and function. Proteins Struct. Funct. Bioinform. 1996, 24, 81-91. [CrossRef]

11. Silva, J.L.; Weber, G. Pressure stability of proteins. Annu. Rev. Phys. Chem. 1993, 44, 89-113. [CrossRef]

12. Balny, C.; Masson, P. Effects of high pressure on proteins. Food Rev. Int. 1993, 9, 611-628. [CrossRef]

13. Considine, T.; Patel, H.A.; Singh, H.; Creamer, L.K. Influence of binding conjugated linoleic acid and myristic acid on the heat-and high-pressure-induced unfolding and aggregation of $\beta$-lactoglobulin B. Food Chem. 2007, 102, 1270-1280. [CrossRef]

14. Tolgyesi, F.; Bode, C.; Smeller, L.; Kim, D.; Kim, K.; Heremans, K.; Fidy, J. Pressure activation of the chaperone function of small heat shock proteins. Cell. Mol. Biol. 2004, 50, 361-370.

15. Hajós, G.; Polgár, M.; Farkas, J. High-pressure effects on IgE immunoreactivity of proteins in a sausage batter. Innov. Food Sci. Emerg. Technol. 2004, 5, 443-449. [CrossRef]

16. Dhakal, S.; Liu, C.; Zhang, Y.; Roux, K.H.; Sathe, S.K.; Balasubramaniam, V.M. Effect of high pressure processing on the immunoreactivity of almond milk. Food Res. Int. 2014, 62, 215-222. [CrossRef]

17. Kleber, N.; Maier, S.; Hinrichs, J. Antigenic response of bovine $\beta$-lactoglobulin influenced by ultra-high pressure treatment and temperature. Innov. Food Sci. Emerg. Technol. 2007, 8, 39-45. [CrossRef]

18. Cuadrado, C.; Sanchiz, A.; Vicente, F.; Ballesteros, I.; Linacero, R. Changes Induced by Pressure Processing on Immunoreactive Proteins of Tree Nuts. Molecules 2020, 25, 954. [CrossRef] [PubMed]

19. Li, Y.; Yang, W.; Chung, S.Y.; Chen, H.; Ye, M.; Teixeira, A.A.; Gregory, J.F.; Welt, B.A.; Shriver, S. Effect of pulsed ultraviolet light and high hydrostatic pressure on the antigenicity of almond protein extracts. Food Bioprocess. Technol. 2013, 6, 431-440. [CrossRef]

20. Husband, F.A.; Aldick, T.; Van der Plancken, I.; Grauwet, T.; Hendrickx, M.; Skypala, I.; Mackie, A.R. High-pressure treatment reduces the immunoreactivity of the major allergens in apple and celeriac. Mol. Nutr. Food Res. 2011, 55, 1087-1095. [CrossRef]

21. Johnson, P.E.; Van der Plancken, I.; Balasa, A.; Husband, F.A.; Grauwet, T.; Hendrickx, M.; Knorr, D.; Mills, E.N.; Mackie, A.R High pressure, thermal and pulsed electric-field-induced structural changes in selected food allergens. Mol. Nutr. Food Res. 2010, 54, 1701-1710. [CrossRef]

22. Somkuti, J.; Bublin, M.; Breiteneder, H.; Smeller, L. Pressure-temperature stability, Ca2+ binding, and pressure-temperature phase diagram of cod parvalbumin: Gad m 1. Biochemistry 2012, 51, 5903-5911. [CrossRef]

23. Liu, C.; Tao, S.; Liu, R.; Chen, F.; Xue, W. Is high pressure treatment able to modify the allergenicity of the largemouth bass allergens? High. Press. Res. 2021, 32, 551-556. [CrossRef]

24. López-Fandiño, R. Functional improvement of milk whey proteins induced by high hydrostatic pressure. Crit. Rev. Food Sci. Nutr. 2006, 46, 351-363. [CrossRef]

25. Rivalain, N.; Roquain, J.; Demazeau, G. Development of high hydrostatic pressure in biosciences: Pressure effect on biological structures and potential applications in biotechnologies. Biotechnol. Adv. 2010, 28, 659-672. [CrossRef] [PubMed]

26. Park, S.; Namkung, H.; Ahn, H.; Paik, I. Production of iron enriched eggs of laying hens. Asian-Australas. J. Anim. Sci. 2004, 17, 1725-1728. [CrossRef]

27. De Maria, S.; Ferrari, G.; Maresca, P. Effect of high hydrostatic pressure on the enzymatic hydrolysis of bovine serum albumin. J. Sci. Food Agric. 2017, 97, 3151-3158. [CrossRef] [PubMed]

28. Chicón, R.; López-Fandiño, R.; Alonso, E.; Belloque, J. Proteolytic pattern, antigenicity, and serum immunoglobulin E binding of $\beta$-lactoglobulin hydrolysates obtained by pepsin and high-pressure treatments. J. Dairy Sci. 2008, 91, 928-938. [CrossRef] [PubMed]

29. Boukil, A.; Suwal, S.; Chamberland, J.; Pouliot, Y.; Doyen, A. Ultrafiltration performance and recovery of bioactive peptides after fractionation of tryptic hydrolysate generated from pressure-treated $\beta$-lactoglobulin. J. Membr. Sci. 2018, 556, 42-53. [CrossRef]

30. Olsen, K.; Kristiansen, K.R.; Skibsted, L.H. Effect of high hydrostatic pressure on the steady-state kinetics of tryptic hydrolysis of ß-lactoglobulin. Food Chem. 2003, 80, 255-260. [CrossRef]

31. Zeece, M.; Huppertz, T.; Kelly, A. Effect of high-pressure treatment on in-vitro digestibility of $\beta$-lactoglobulin. Innov. Food Sci. Emerg. Technol. 2008, 9, 62-69. [CrossRef]

32. Izquierdo, F.J.; Alli, I.; Gómez, R.; Ramaswamy, H.S.; Yaylayan, V. Effects of high pressure and microwave on pronase and $\alpha$-chymotrypsin hydrolysis of $\beta$-lactoglobulin. Food Chem. 2005, 92, 713-719. [CrossRef]

33. Blayo, C.; Vidcoq, O.; Lazennec, F.; Dumay, E. Effects of high pressure processing (hydrostatic high pressure and ultra-high pressure homogenisation) on whey protein native state and susceptibility to tryptic hydrolysis at atmospheric pressure. Food Res. Int. 2016, 79, 40-53. [CrossRef]

34. Beran, M.; Klubal, R.; Molik, P.; Strohalm, J.; Urban, M.; Klaudyova, A.A.; Prajzlerova, K. Influence of high-hydrostatic pressure on tryptic and chymotryptic hydrolysis of milk proteins. High. Press. Res. 2009, 29, 23-27. [CrossRef]

35. Bamdad, F.; Shin, S.H.; Suh, J.-W.; Nimalaratne, C.; Sunwoo, H. Anti-inflammatory and antioxidant properties of casein hydrolysate produced using high hydrostatic pressure combined with proteolytic enzymes. Molecules 2017, 22, 609. [CrossRef]

36. Knudsen, J.; Otte, J.; Olsen, K.; Skibsted, L. Effect of high hydrostatic pressure on the conformation of $\beta$-lactoglobulin A as assessed by proteolytic peptide profiling. Int. Dairy J. 2002, 12, 791-803. [CrossRef] 
37. Maynard, F.; Weingand, A.; Hau, J.; Jost, R. Effect of high-pressure treatment on the tryptic hydrolysis of bovine $\beta$-lactoglobulin AB. Int. Dairy J. 1998, 8, 125-133. [CrossRef]

38. Lozano-Ojalvo, D.; Pérez-Rodríguez, L.; Pablos-Tanarro, A.; López-Fandiño, R.; Molina, E. Pepsin treatment of whey proteins under high pressure produces hypoallergenic hydrolysates. Innov. Food Sci. Emerg. Technol. 2017, 43, 154-162. [CrossRef]

39. Marciniak, A.; Suwal, S.; Brisson, G.; Britten, M.; Pouliot, Y.; Doyen, A.J.F.H. Studying a chaperone-like effect of beta-casein on pressure-induced aggregation of beta-lactoglobulin in the presence of alpha-lactalbumin. Food Hydrocoll. 2018, 84, 9-15. [CrossRef]

40. Zhao, Y.; Sun, X.; Marquis, C.P.; Lee, N.A. Development of a sensitive sandwich ELISA specific to 2S albumin (Ana o 3) as a stable protein marker for cashew nut residue detection in pre-packaged food products. Food Control 2019, 96, 432-440. [CrossRef]

41. Yang, J.; Dunker, A.K.; Powers, J.R.; Clark, S.; Swanson, B.G. $\beta$-Lactoglobulin molten globule induced by high pressure. J. Agric. Food Chem. 2001, 49, 3236-3243. [CrossRef]

42. Karamonová, L.; Fukal, L.; Kodíček, M.; Rauch, P.; Mills, E.C.; Morgan 1, M.R. Immunoprobes for thermally-induced alterations in whey protein structure and their application to the analysis of thermally-treated milks. Food Agric. Immunol. 2003, 15, 77-91. [CrossRef]

43. Manderson, G.A.; Creamer, L.K.; Hardman, M.J. Effect of heat treatment on the circular dichroism spectra of bovine $\beta$ lactoglobulin A, B, and C. J. Agric. Food Chem. 1999, 47, 4557-4567. [CrossRef]

44. Meng, X.; Bai, Y.; Gao, J.; Li, X.; Chen, H. Effects of high hydrostatic pressure on the structure and potential allergenicity of the major allergen bovine $\beta$-lactoglobulin. Food Chem. 2017, 219, 290-296. [CrossRef] [PubMed]

45. Svenning, C.; Brynhildsvold, J.; Molland, T.; Langsrud, T.; Vegarud, G.E. Antigenic response of whey proteins and genetic variants of $\beta$-lactoglobulin-The effect of proteolysis and processing. Int. Dairy J. 2000, 10, 699-711. [CrossRef]

46. Considine, T.; Patel, H.A.; Anema, S.G.; Singh, H.; Creamer, L.K. Interactions of milk proteins during heat and high hydrostatic pressure treatments-A Review. Innov. Food Sci. Emerg. Technol. 2007, 8, 1-23.

47. Clement, G.; Boquet, D.; Frobert, Y.; Bernard, H.; Negroni, L.; Chatel, J.-M.; Adel-Patient, K.; Creminon, C.; Wal, J.-M.; Grassi, J. Epitopic characterization of native bovine $\beta$-lactoglobulin. J. Immunol. Methods 2002, 266, 67-78. [CrossRef]

48. Chikenji, G.; Kikuchi, M. What is the role of non-native intermediates of $\beta$-lactoglobulin in protein folding? Proc. Natl. Acad. Sci. USA 2000, 97, 14273-14277. [CrossRef]

49. Jegouic, M.; Grinberg, V.Y.; Guingant, A.; Haertlé, T. Thiol-induced oligomerization of $\alpha$-lactalbumin at high pressure. J. Protein Chem. 1996, 15, 501-509. [CrossRef]

50. Hong, Y.-H.; Creamer, L.K. Changed protein structures of bovine $\beta$-lactoglobulin B and $\alpha$-lactalbumin as a consequence of heat treatment. Int. Dairy J. 2002, 12, 345-359. [CrossRef]

51. Dalgleish, D.G.; Senaratne, V.; Francois, S. Interactions between $\alpha$-lactalbumin and $\beta$-lactoglobulin in the early stages of heat denaturation. J. Agric. Food Chem. 1997, 45, 3459-3464. [CrossRef]

52. Calvo, M.M.; Leaver, J.; Banks, J.M. Influence of other whey proteins on the heat-induced aggregation of $\alpha$-lactalbumin. Int. Dairy J. 1993, 3, 719-727. [CrossRef]

53. Hochwallner, H.; Schulmeister, U.; Swoboda, I.; Balic, N.; Geller, B.; Nystrand, M.; Härlin, A.; Thalhamer, J.; Scheiblhofer, S.; Niggemann, B. Microarray and allergenic activity assessment of milk allergens. Clin. Exp. Allergy 2010, 40, 1809-1818. [CrossRef] [PubMed]

54. Alessandri, S.; Sancho, A.; Vieths, S.; Mills, C.E.; Wal, J.-M.; Shewry, P.R.; Rigby, N.; Hoffmann-Sommergruber, K. High-throughput NMR assessment of the tertiary structure of food allergens. PLoS ONE 2012, 7, e39785. [CrossRef]

55. Wal, J.-M. Cow's milk proteins/allergens. Ann. Allergy Asthma Immunol. 2002, 89, 3-10. [CrossRef]

56. Patel, H.A.; Singh, H.; Anema, S.G.; Creamer, L.K. Effects of heat and high hydrostatic pressure treatments on disulfide bonding interchanges among the proteins in skim milk. J. Agric. Food Chem. 2006, 54, 3409-3420. [CrossRef]

57. Huppertz, T.; Vasiljevic, T.; Zisu, B.; Deeth, H. Novel processing technologies: Effects on whey protein structure and functionality. In Whey Proteins; Academic Press: London, UK, 2019; pp. 281-334.

58. McSweeney, P.L.; O'Mahony, J.A. Advanced Dairy Chemistry: Volume 1B: Proteins: Applied Aspects; Springer: New York, NY, USA, 2016.

59. Rattray, W.; Jelen, P. Thermal stability of skim milk/whey protein solution blends. Food Res. Int. 1997, 30, 327-334. [CrossRef]

60. Chaplin, L.C.; Lyster, R.L. Irreversible heat denaturation of bovine $\alpha$-lactalbumin. J. Dairy Res. 1986, 53, 249-258. [CrossRef] 